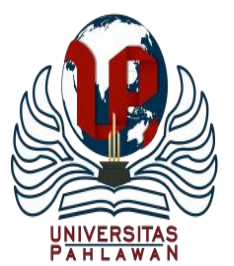

Edukatif : Jurnal Ilmu Pendidikan Volume 2 Nomor 3 Tahun 2020 Halm 253 - 268

EDUKATIF: JURNAL ILMU PENDIDIKAN

Research \& Learning in Education

https://edukatif.org/index.php/edukatif/index

\title{
Investigation of Junior and Senior High School Students' Attitudes Towards Correcting Mistakes: A Case Study In Guilin
}

\author{
Xinxing Deng ${ }^{1}$, Ying Zhou ${ }^{2}$, Cunhua Liu ${ }^{3}$ \\ Department of Mathematics and Statistics, Guangxi Normal University, China ${ }^{1,2}$ \\ No.2 Junior High School, Nanning, Guangxi, China ${ }^{3}$ \\ E-mail : $\underline{1397527371 @ q q . c o m}{ }^{1} \underline{\text { zhouying66@mailbox.gxnu.edu.cn }}^{2} \underline{1216582371 @ q q . c o m}^{3}$
}

\begin{abstract}
Abstrak
Sikap siswa dalam mengoreksi soal matematika yang salah mempengaruhi efek pembelajaran matematika sampai batas tertentu. Berfokus pada sikap siswa dalam mengoreksi soal matematika yang salah, menemukan masalah dari akar penyebabnya dapat memberikan dasar penting untuk mengoreksi perilaku. Penelitian ini menggunakan metode kuantitatif deskriptif. Pengambilan data menggunakan kuesioner. Sampel penelitian ini adalah 622 siswa di Guilin, Cina. Hasil kuesioner diolah dengan menggunakan Microsoft Excel dan SPSS. Siswa mengisi kuisioner skala Sikap terhadap Mengoreksi Pertanyaan Salah. Skala untuk mengetahui sikap siswa SMP dalam mengoreksi soal matematika yang salah dari tiga dimensi yaitu kognitif, kecenderungan sikap dan emosi. Penelitian ini menemukan bahwa: 1) secara keseluruhan tingkat sikap siswa sekolah menengah pertama terhadap mengoreksi soal matematika yang salah relatif tinggi; 2) terdapat perbedaan dalam tiga dimensi, yaitu tingkat kognitif $>$ tingkat emosi> kecenderungan perilaku; 3) ada perbedaan yang signifikan dalam sikap mengoreksi soal matematika yang salah dalam gender, apakah mereka ketua kelas atau bukan, apakah walikelas adalah guru matematika; 4) ada korelasi yang signifikan antara setiap dimensi dan kinerja akademik matematika dan 5) sikap mengoreksi soal matematika yang salah berpengaruh positif signifikan terhadap kinerja akademik matematika.
\end{abstract}

Kata kunci: mengoreksi kesalahan, prestasi akademik, sikap siswa

\section{Abstract}

Students' attitudes towards correcting mathematics wrong questions affect the effect of mathematics learning to a certain extent. Focusing on students' attitudes towards correcting maths wrong questions, discovering the problem from the root cause can provide an important basis for correcting behavior. This research uses quantitative methods. the data were taken using a questionnaire. The sample of this study was 622 students in Guilin, China. The results of the questionnaire were processed using Microsoft Word and SPSS. the students filled out a questionnaire Attitudes towards Correcting Mathematics Wrong Questions Scale to investigate the attitudes of junior and senior high school students to correcting mathematics wrong questions from the three dimensions of cognition, behavior tendency and emotion. This research found 1) the overall level of Junior and senior high school students' attitudes towards correcting mathematics wrong questions is relatively high; 2) There are differences in the three dimensions, that is, cognitive level>emotional level>behavioral tendency; 3) there are significant differences in the attitude of correcting mathematics wrong questions in gender, whether or not they are student leaders, whether the head teacher is a math teacher, and grade; 4) And there is a significant correlation between each dimension and mathematics academic performance; 5) the attitude of correcting mathematics wrong questions significantly positively affects mathematics academic performance.

Keywords: correcting mistake, academic performance, student attitude

Copyright (c) 2020 Xinxing Deng, Ying Zhou, Cunhua Liu

$\triangle$ Corresponding author

Address : Yucai Road no 15 Guilin, Guangxi, China

Email : zhouying66@mailbox.gxnu.edu.cn

Phone : +8613978306100

DOI: https://doi.org/10.31004/edukatif.v2i3.158
ISSN 2656-8063 (Media Cetak)

ISSN 2656-8071 (Media Online)

Edukatif : Jurnal Ilmu Pendidikan Vol 2 No 3 Tahun 2020 p-ISSN 2656-8063 e-ISSN 2656-8071 


\section{INTRODUCTION}

In the PISA results, Chinese students achievement in mathematics got satisfactory results (Retnawati \& Wulandari, 2019; Yang \& Sianturi, 2017). However, efforts to improve mathematics learning outcomes are still being carried out and analyzed (Aixia, Ying, \& Wijaya, 2020). Because mathematics education is dynamic And always changes according to circumstances. So from this research in various aspects with the aim of improving students' mathematical abilities is still being carried out (Chai, Lim, \& Tan, 2016; T.T. Wijaya, Tang, \& Purnama, 2020; Zhang, Zhou, \& Wijaya, 2020). These research studies include the use of technology-based learning media (T.T. Wijaya, Ying, Chotimah, et al., 2020; T.T. Wijaya, Ying, \& Purnama, 2020), the use of video-based learning media (Huang et al., 2020; Tommy Tanu Wijaya, 2021), the comparison of mathematics textbooks (Aditya, Wijaya, Dewi, \& Zulfah, 2020; Fan, Zhu, \& Miao, 2013; Yang \& Sianturi, 2017; Yang, Tseng, \& Wang, 2017), development of questions that require high-level thinking (Surya, Zulfah, Astuti, Marta, \& Wijaya, 2020; Zulfah, Astuti, Surya, Marta, \& Wijaya, 2020).

Many studies have been conducted on the analysis of student errors in doing questions at the elementary (Pertiwi \& Wahyudin, 2020; Takeuchi \& Shinno, 2020), junior high school (Nurfauziah, Faudziah, Nuryatin, \& Mustaqimah, 2018; Qin, Zhou, \& Tanu, 2019; Sari \& Wutsqa, 2019; Shinariko, Saputri, Hartono, \& Araiku, 2020; Susanti \& Hartono, 2019), and high school levels (Jatmiko, Fatahillah, Oktavianingtyas, \&
Rochmah, 2020; Laelasari, Darhim, \& Prabawanto, 2019; Mumcu \& Aktaş, 2020). But only a few studies have analyzed how students behave when they correct math problems.

Wrong questions have the effect of improving students' problem-solving ability and perfecting cognitive structure." mathematics wrong questions are valuable teaching resources. "General High School Mathematics Curriculum Standards (2017 Edition)" pointed out (Yi, Ying, \& Wijaya, 2019): students should have the ability to reflect and be able to build a knowledge system independently. evaluation is an effective way of learning mathematics.

According to Dewey's reflective thinking (Parsons, Inkila, \& Lynch, 2019; Shieh \& Chang, 2014), correcting mathematics errors is a process of evaluation and an effective way to improve mathematics performance. In addition, the materials of the Nineteenth International Conference on National Education of UNESCO also pointed out : "The mistakes made by students should be studied, and mistakes should be regarded as a means of understanding the law of students' thinking." It can be seen that mathematics is wrong. Often plays an important role. Although the value of mathematics mistakes and corrections is widely recognized, the research on mathematics mistakes and corrections of mathematics mistakes at home and abroad mostly focuses on attribution analysis, classification, and management of wrong questions. Some involved students' attitudes towards correcting a mistake. As the saying goes, "Attitude is everything". From Kraus's analysis of 88 "attitude-behavior" studies (Villalba-condori, 
255 Investigation of Junior and Senior High School Students' Attitudes Towards Correcting Mistakes: A Case Study In Guilin - Xinxing Deng, Ying Zhou, Cunhua Liu

DOI: https://doi.org/10.31004/edukatif.v2i3.158

Lavonen, \& Eds, 2019; Xu, Wu, \& Wang, 2020), it is easy to know that there is a very close relationship between attitude and behavior.

In view of this, this research adopts the "Junior and senior high school Students' Attitudes towards Correcting Mathematics Wrong Questions" to quantify the current situation of Junior and senior high school students' attitudes towards correcting mathematics wrong questions, to explore the differences in demographic variables, and to analyze the reasons for the students' Learning and teachers' teaching provide some enlightenment.

This article intends to study from the following questions: (1) What is the overall level of Junior and senior high school students' attitudes towards correcting mathematics errors? (2) Are there any significant differences in the grades of Junior and senior high school students' attitudes towards correcting mathematics wrong questions and various dimensions? (3) Are there any significant gender differences in Junior and senior high school students' attitudes towards correcting mathematics wrong questions and various dimensions? (4) Are there significant differences in the Junior and senior high school students' attitudes towards correcting mathematics wrong questions and various dimensions among the student leaders? (5) Are there significant differences in the Junior and senior high school students' attitudes towards correcting mathematics wrong questions and various dimensions in the teaching subjects of the head teacher? (6) Are there any significant correlations between Junior and senior high school students' attitudes towards correcting mathematics wrong questions and the various dimensions and mathematics academic performance? (7) Does the attitude of Junior and senior high school students in correcting mathematics wrong questions significantly positively affect their mathematics academic performance?

The purpose of this research is to conduct a questionnaire survey and use effective questionnaire data to analyze the status quo of Junior and senior high school students' attitudes towards correcting mathematics wrong questions, explore the relationship between their attitudes towards correcting mathematics wrong questions and their academic performance, and provide a theory for correcting their attitudes towards correcting mathematics wrong questions. Basis and empirical support. Specifically, the research objectives of this article mainly include these aspects: (1) To understand the overall level of Junior and senior high school students' attitudes towards correcting mathematics wrong questions; (2) To explore whether there are significant differences in the grades of Junior and senior high school students' attitudes towards correcting mistake.mathematics wrong questions; (3) Analyze whether there are significant differences in the attitudes of Junior and senior high school students in correcting mathematics wrong questions and whether there are significant gender differences in each dimension; (4) Explore whether there are significant differences in Junior and senior high school students' attitudes to correcting mathematics wrong questions and each dimension in student leaders; (5) Analyze Junior and senior 
256 Investigation of Junior and Senior High School Students' Attitudes Towards Correcting Mistakes: A Case Study In Guilin - Xinxing Deng, Ying Zhou, Cunhua Liu

DOI: https://doi.org/10.31004/edukatif.v2i3.158

high school students in correcting mathematics Whether there are significant differences in the attitudes of wrong questions and various dimensions in the teaching subjects of the teacher in charge; (6) Explore the attitudes of Junior and senior high school students to correct mathematics wrong questions and the correlation between each dimension and mathematics academic performance; (7) Analyze the correct attitudes of Junior and senior high school students to correct mathematics wrong questions The influence of mathematics academic performance; (8) Analyze and discuss the results of hypothesis testing, and put forward corresponding enlightenment and suggestions for how to correct students' attitudes towards correcting mathematics mistakes and improve students' mathematics academic performance.

The findings of this study will be groundbreaking, with a novel perspective and valuable research content. Through combing the relevant literature, it is found that most of the existing research on Junior and Senior High school students' mathematics academic performance focuses on the management of wrong questions, while empirical research on the attitudes to correcting mathematics wrong questions is relatively rare, especially the correcting attitudes to mathematics wrong questions and mathematics academic performance Related empirical research is even scarcer. Therefore, this study broadens the research field of mathematics error management, enriches the research results of mathematics academic performance, and can provide important theoretical and empirical basis for subsequent research

\section{METHOD}

\section{Sample and population}

In this study, cluster sampling was used. The survey subjects were selected from Guidian Junior and Senior High School in Guilin City, Guangxi. Among the six grades of the school from from grade 7 to grade 12 (junior and senior high school), students from two classes were randomly selected as subjects in each grade. A total of 622 questionnaires were issued and 575 questionnaires were returned, with an effective response rate of $92.4 \%$. The basic information of the subjects is shown in Table 1.

This research uses the "Junior and Senior High School Students' Attitudes towards Correcting Mathematics Wrong Questions" as a measuring tool, with a total of 27 items (including 7 reverse Questions), in the form of a questionnaire, the test time is about 10 minutes.

Table 1. Basic Information Table Of Sampled Subjects

\begin{tabular}{|c|c|c|c|c|c|c|c|c|c|c|c|c|}
\hline sample & \multicolumn{2}{|c|}{ Sex } & \multicolumn{2}{|c|}{$\begin{array}{c}\text { Is a student } \\
\text { leader? }\end{array}$} & \multicolumn{4}{|c|}{ Class teacher } & \multicolumn{5}{c|}{ Grade } \\
\cline { 2 - 12 } & male & female & Yes & No & $\begin{array}{c}\text { Mathematics } \\
\text { Teacher }\end{array}$ & $\begin{array}{c}\text { Except } \\
\text { mathematics } \\
\text { teacher }\end{array}$ & VII & VIII & IX & X & XI & XII \\
\hline $\begin{array}{c}\text { Total } \\
\text { students }\end{array}$ & 272 & 303 & 199 & 376 & 306 & 269 & 105 & 100 & 110 & 111 & 77 & 72 \\
\hline
\end{tabular}


257 Investigation of Junior and Senior High School Students' Attitudes Towards Correcting Mistakes: A Case Study In Guilin - Xinxing Deng, Ying Zhou, Cunhua Liu

DOI: https://doi.org/10.31004/edukatif.v2i3.158

This questionnaire consists of three parts: instruction, basic personal information and scale. Among them, the basic personal information includes gender, whether a student leader, whether the head teacher is a math teacher, grade, mathematics scores in the mid-term exam, and math scores in the final exam (table 2). The scale uses Likert's 5-point scoring method, "completely inconsistent", "rarely consistent", "somewhat consistent", "relatively consistent" and "completely consistent" are counted as 1 to 5 points respectively. The attitude becomes more correct

\section{Reliability and validity of questionnaire}

This study uses Cronbach's $\alpha$ coefficient (also known as internal consistency $\alpha$ coefficient) to test the reliability of the questionnaire. The higher the coefficient, the better the reliability index. Use SPSS21.0 to analyze the reliability of the collected 575 valid questionnaires. The results are shown in Table 3. It can be seen that the internal consistency $\alpha$ coefficient value of the scale is equal to 0.924 , and the subscale "cognition of corrected mathematics wrong questions (hereinafter referred to as "cognition")" and "behavioral tendency of corrected mathematical wrong questions (below The Cronbach's $\alpha$ coefficients of "behavioral tendency") and "emotion for correcting mathematical errors (hereinafter referred to as "emotion")" are 0.924, 0.862 , and 0.742 , respectively, indicating the reliability index of the total scale and subscale Both are ideal.

The question items of the scale used in this study are derived from the "High School Students' Attitudes towards Correcting Mathematics Wrong Questions Scale" compiled by Liu Ting and others. The indicators of the scale meet the measurement requirements, which shows that it has good structural validity. And before the survey, this scale has undergone a group discussion by some Junior and Senior High school students, frontline teachers, tutors, and graduate students in mathematics of the school, and has been highly and well evaluated, which guarantees the validity of the scale to a certain extent. . In this study, the KMO value of the scale was 0.925 , and three factors were limited in the principal component analysis method, and the joint explained variance was $52.270 \%$, indicating that the three factors are appropriate. Therefore, this scale has good reliability and validity.

Tabel 2. Questionnaire Students' Attitudes Towards Correcting Mathematics Wrong Questions

\begin{tabular}{|c|l|}
\hline & \multicolumn{1}{c|}{ Questioner } \\
\hline \multirow{2}{*}{$\begin{array}{c}\text { Cognition of } \\
\text { Correcting Wrong } \\
\begin{array}{c}\text { Problems in } \\
\text { Mathematics }\end{array}\end{array}$} & $\begin{array}{l}\text { 1. Correcting the wrong math problem is not just solving the problem again, but } \\
\text { more importantly, finding the cause of the error. }\end{array}$ \\
\cline { 2 - 2 } & $\begin{array}{l}\text { 2. Correcting the mathematics wrong questions can check the omissions and } \\
\text { improve my mathematics knowledge system. }\end{array}$ \\
\cline { 2 - 2 } & 3. Correcting mathematics wrong questions can deepen my understanding of \\
\hline
\end{tabular}




\begin{tabular}{|c|c|}
\hline & \\
\hline & $\begin{array}{l}\text { 4. Correcting wrong math problems can strengthen my memory of the standard } \\
\text { format for solving problems. }\end{array}$ \\
\hline & $\begin{array}{l}\text { 5. Correcting mathematics wrong questions is to check for omissions and improve } \\
\text { my mathematics knowledge system. }\end{array}$ \\
\hline & $\begin{array}{l}\text { 6. Correcting mathematics wrong questions is to deepen my understanding of } \\
\text { mathematics knowledge and mastery of problem-solving methods. }\end{array}$ \\
\hline & $\begin{array}{l}\text { 7. Correcting mathematics wrong questions is to correct my misunderstanding of } \\
\text { certain mathematical knowledge or problem-solving methods. }\end{array}$ \\
\hline \multirow{13}{*}{$\begin{array}{l}\text { Behavioral Tendency } \\
\text { to Correct } \\
\text { Mathematical } \\
\text { Problems }\end{array}$} & $\begin{array}{l}\text { 8. For maths wrong questions that have not been corrected through many channels } \\
\text { (such as checking information online, consulting classmates, etc.), I still want to } \\
\text { ask the teacher if time permits. }\end{array}$ \\
\hline & $\begin{array}{l}\text { 9. If I want to play (such as playing with my mobile phone, reading novels, etc.), I } \\
\text { still hope to play again after correcting the wrong math problems. }\end{array}$ \\
\hline & $\begin{array}{l}\text { 10. I believe that I can correct all mathematics wrong questions through various } \\
\text { means (such as checking information online, consulting classmates or teachers, } \\
\text { etc.). }\end{array}$ \\
\hline & 11. If time is tight, I also hope to find time to correct math problems. \\
\hline & $\begin{array}{l}\text { 12. If there are people playing around (for example, playing mobile phones, } \\
\text { reading novels, etc.), I don't want to correct the wrong math problem. }\end{array}$ \\
\hline & $\begin{array}{l}\text { 13. If the students around me are doing homework, I don't want to correct the } \\
\text { wrong math problem. }\end{array}$ \\
\hline & $\begin{array}{l}\text { 14. When correcting a math problem, if it is blocked while seeking help, I don't } \\
\text { want to correct it if time permits. }\end{array}$ \\
\hline & $\begin{array}{l}\text { 15. I did not want to correct the mathematics wrong questions that could not be } \\
\text { corrected in time due to various reasons. Time permits. }\end{array}$ \\
\hline & $\begin{array}{l}\text { 16. When correcting a math problem, if time permits, I hope to write the process } \\
\text { of solving the problem next to the problem. }\end{array}$ \\
\hline & $\begin{array}{l}\text { 17. After correcting the mathematics wrong question, if time permits, I hope to } \\
\text { indicate the reason for the wrong question beside the question. }\end{array}$ \\
\hline & $\begin{array}{l}\text { 18. After correcting the mathematics wrong question, if time permits, I hope to } \\
\text { analyze the cause of the error from the perspective of the mastery of mathematical } \\
\text { knowledge points. }\end{array}$ \\
\hline & $\begin{array}{l}\text { 19. When correcting a math problem, if time permits, I hope to mark the key } \\
\text { points. }\end{array}$ \\
\hline & $\begin{array}{l}\text { 20. After correcting the wrong math problems, if time permits, I hope to } \\
\text { summarize the ideas and methods for solving such math problems. }\end{array}$ \\
\hline $\begin{array}{l}\text { Emotion for } \\
\text { correcting wrong } \\
\text { math problems }\end{array}$ & $\begin{array}{l}\text { 21. I am happy to correct the wrong math problems. } \\
\text { 22. Correcting mathematics errors is a tedious process. } \\
\text { 23. Anyway, I may make similar mistakes again after the correction, so there is no } \\
\text { need to correct the math wrong. } \\
\text { 24. I feel upset at the thought of correcting wrong math problems. } \\
\text { 25. I feel very uncomfortable when I encounter a math problem that I cannot } \\
\text { correct. } \\
\text { 26. I find it uncomfortable for mathematics wrong questions that have not been }\end{array}$ \\
\hline
\end{tabular}

Edukatif : Jurnal Ilmu Pendidikan Vol 2 No 3 Tahun 2020 p-ISSN 2656-8063 e-ISSN 2656-8071 
259 Investigation of Junior and Senior High School Students' Attitudes Towards Correcting Mistakes: A Case Study In Guilin - Xinxing Deng, Ying Zhou, Cunhua Liu

DOI: https://doi.org/10.31004/edukatif.v2i3.158

thoroughly understood.

27. I can't let go of the mathematics errors that cannot be corrected in time.

Table 3 reliability statistics (Cronbach's $\alpha$ coefficient)

\begin{tabular}{|c|c|c|c|c|}
\hline & Cognition & Behavioral Tendency & Emotion & $\begin{array}{c}\text { Attitude toward correcting } \\
\text { mistake }\end{array}$ \\
\hline Cronbach's acoefficient & 0.924 & 0.862 & 0.742 & 0.924 \\
\hline Standard Cronbach's $\alpha$ & 0.925 & 0.861 & 0.749 & 0.927 \\
\hline
\end{tabular}

\section{RESULTS AND DISCUSSION}

The overall level of Junior and Senior High school students' attitudes towards correcting wrong mathematics questions

Table 4 The overall level of Junior and Senior High school students' attitudes towards correcting mathematics wrong questions

\begin{tabular}{|c|c|c|c|}
\hline Variable & $\mathbf{N}$ & $\mathbf{M}$ & $\mathbf{S D}$ \\
\hline $\begin{array}{c}\text { Awareness of correcting wrong } \\
\text { math problems }\end{array}$ & 575 & 3.99 & 0.83 \\
\hline $\begin{array}{c}\text { Behavioral tendency to correct } \\
\text { wrong math problems }\end{array}$ & 575 & 3.64 & 0.74 \\
\hline $\begin{array}{c}\text { Emotion for correcting wrong } \\
\text { math problems }\end{array}$ & 575 & 3.80 & 0.74 \\
\hline $\begin{array}{c}\text { Attitude to correct wrong math } \\
\text { problems }\end{array}$ & 575 & 3.77 & 0.67 \\
\hline
\end{tabular}

Note: $\mathrm{N}=$ the number of students, $\mathrm{M}=$ the mean,

$\mathrm{SD}=$ the standard deviation

It can be seen from Table 4 that the average

value of Junior and Senior High school students' attitudes towards correcting maths wrong questions is 3.77 , indicating that the overall level of Junior and Senior High school students' attitudes towards correcting maths wrong questions is relatively high, and they have a more positive psychological tendency towards "correcting maths wrong questions". Among them, the average value of the behavioral orientation dimension for correcting correcting mistake is the lowest $(M=3.64)$, and the average value of the cognitive dimension for correcting correcting mistake is the highest $(\mathrm{M}=3.99)$.

\section{The Grade Differences and Developmental Changes of Junior and Senior High School Students' Attitudes to Correcting Mistakes in Mathematics}

Table 5 Analysis of grade differences in Junior and Senior High school students' attitudes towards correcting mathematics wrong questions

\begin{tabular}{|l|l|l|l|l|l|l|l|}
\hline variable & VII & VIII & IX & X & XI & XII & F test \\
\hline $\begin{array}{l}\text { Cognition of Correcting Wrong } \\
\text { Problems in Mathematics }\end{array}$ & $4.04 \pm 0.71$ & $3.79 \pm 0.85$ & $4.22 \pm 0.71$ & $4.09 \pm 0.73$ & $3.78 \pm 1.01$ & $3.90 \pm 0.98$ & $\begin{array}{l}4.491^{*} \\
*\end{array}$ \\
\hline $\begin{array}{l}\text { Behavioral Tendency to Correct } \\
\text { Mathematical Problems }\end{array}$ & $3.94 \pm 0.65$ & $3.66 \pm 0.75$ & $3.73 \pm 0.64$ & $3.55 \pm 0.72$ & $3.40 \pm 0.80$ & $3.40 \pm 0.80$ & $\begin{array}{l}7.621^{*} \\
* *\end{array}$ \\
\hline $\begin{array}{l}\text { Emotion for correcting wrong } \\
\text { math problems }\end{array}$ & $4.09 \pm 0.60$ & $3.73 \pm 0.80$ & $3.84 \pm 0.65$ & $3.70 \pm 0.65$ & $3.63 \pm 0.87$ & $3.72 \pm 0.86$ & $\begin{array}{l}4.964^{*} \\
* *\end{array}$ \\
\hline $\begin{array}{l}\text { Attitude towards correcting } \\
\text { mathematics wrong questions }\end{array}$ & $4.01 \pm 0.55$ & $3.71 \pm 0.72$ & $3.88 \pm 0.55$ & $3.73 \pm 0.62$ & $3.56 \pm 0.78$ & $3.62 \pm 0.74$ & $\begin{array}{l}6.053^{*} \\
* *\end{array}$ \\
\hline
\end{tabular}




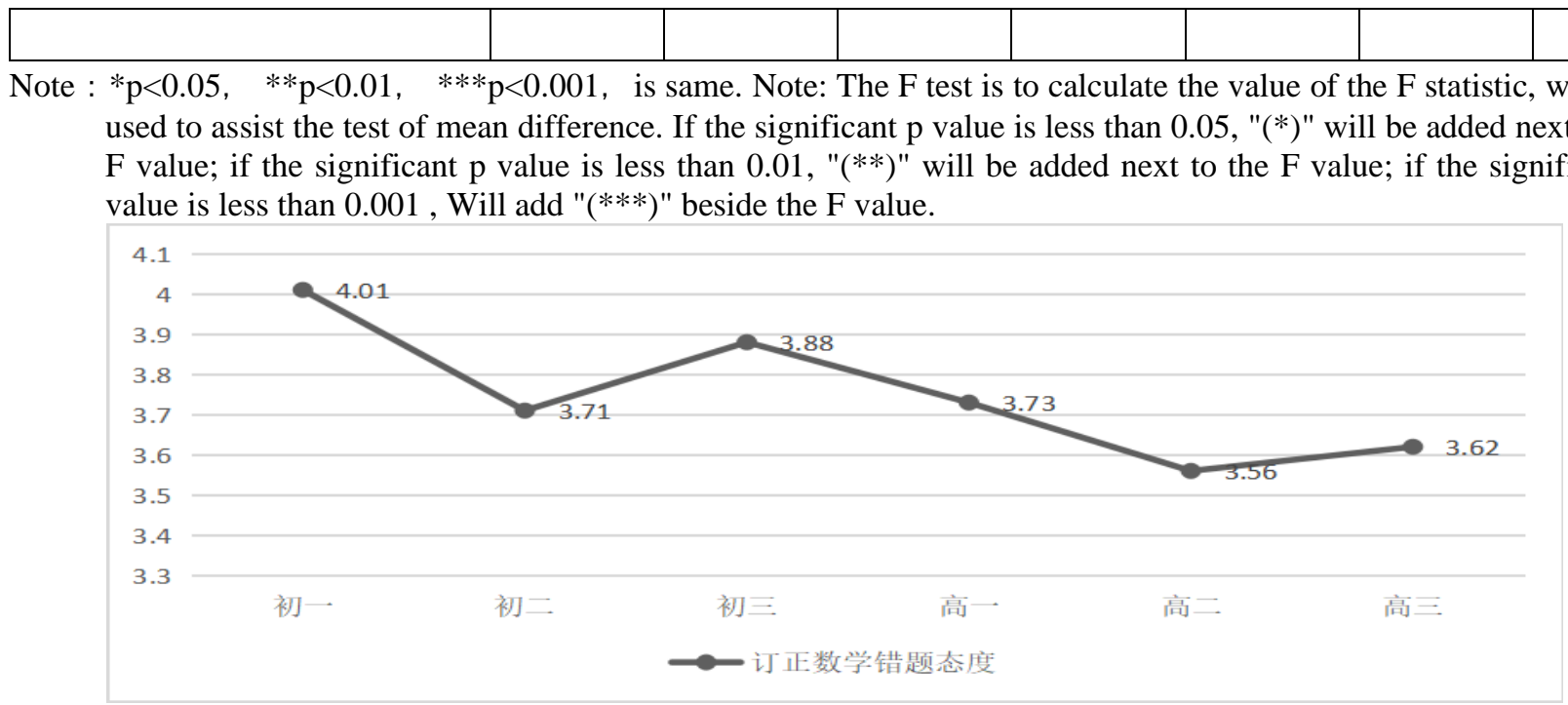

Figure 1. Grade development changes of Junior and Senior High school students' attitudes Correcting Mistakes in Mathematics problem

Since grade is a multi-valued variable, this study uses a one-way analysis of variance test method to judge its relationship with the attitude of correcting mathematics wrong questions. The results are shown in Table 4. It can be seen from Table 5 that there is a note beside the F-values of correcting math wrong attitude and cognition, behavior tendency and emotion, and the significance $\mathrm{p}$-value is less than 0.01 , reaching a significant level, indicating that Junior and Senior High school students' correcting math wrong attitude and cognition, There are significant differences in behavioral orientation and emotional dimensions in grades. In combination with Figure 1 , it can be further found that from the perspective of junior and senior high school or high school, students' attitudes towards correcting wrong questions develop in a "concave" form. Low; from the perspective of the entire Junior and Senior High school, the scores of junior and senior high school students are higher than those of high school students, indicating that junior and senior high school students have a more positive attitude in correcting a mistake.

\section{Gender Differences in Junior and Senior High School Students' Attitudes to Correct Mathematical Error}

Table 6 Gender Differences in Middle School Students' Attitudes to Correcting Mistakes in Mathematics problem

\begin{tabular}{|l|c|c|c|c|c|}
\hline \multicolumn{1}{|c|}{ Variable } & Sex & N & M & SD & t \\
\hline Cognition of Correcting Wrong Problems in Mathematics & Male & 272 & 3.97 & 0.92 & \multirow{2}{*}{-0.618} \\
\cline { 2 - 5 } Behavioral Tendency to Correct Mathematical Problems & Female & 303 & 4.01 & 0.75 & \\
\hline \multirow{2}{*}{ Emotion for correcting wrong math problems } & Male & 272 & 3.56 & 0.84 & \multirow{2}{*}{$-2.408^{*}$} \\
\cline { 2 - 5 } & Female & 303 & 3.71 & 0.63 & \\
\hline Cognition of Correcting Wrong Problems in Mathematics & Male & 272 & 3.70 & 0.85 & \multirow{2}{*}{$-2.917^{* *}$} \\
\cline { 2 - 5 } Behavioral Tendency to Correct Mathematical Problems & Female & 303 & 3.88 & 0.62 & \\
\hline \multirow{2}{*}{ Emotion for correcting wrong math problems } & Male & 272 & 3.70 & 0.77 & \multirow{2}{*}{$-2.322^{*}$} \\
\cline { 2 - 5 } & Female & 303 & 3.83 & 0.56 & \\
\hline
\end{tabular}


Note: $\mathrm{N}=$ the number of students, $\mathrm{M}=$ the mean, $\mathrm{SD}=$ the standard deviation. The $\mathrm{t}$ test is to calculate the value of the $\mathrm{t}$ statistic, which is used for the mean difference test. If the significant $p$ value is greater than 0.05 , no note will be added to the $t$ value; if the significant $p$ value is less than 0.05 , "*)" will be added to the $t$ value; if the significant $\mathrm{p}$ value is less than 0.01 , it will be added to the $\mathrm{t}$ value Add "(**)" beside it.

It can be seen from Table 5 that there are

There is no significant difference in gender

notes beside the $t$-values of correcting mathematics wrong questions attitude and behavior tendency and emotion, and the significance p-values are all less than 0.05 , reaching a significant level. There are significant differences in gender in behavior tendency and affective dimensions of corrected math wrong questions, and girls' attitudes towards correcting math wrong questions, behavioral tendency towards corrected math mistakes, and the mean value of the emotional dimension of corrected math mistakes are significantly higher than Boys. in Junior and Senior High school students' cognition of correcting mathematics errors (there is no note beside the $t$ value of the cognitive dimension, and the significance $\mathrm{p}$ value is greater than 0.05), and the mean value of girls in this dimension $(\mathrm{M}=4.01)$ is slightly higher For boys $(\mathrm{M}=3.97)$.

\section{Whether or not Junior and Senior High school students who are serving as student leaders have different attitudes towards correcting wrong math problems}

Table 7 Differences in attitudes of middle school students who are student leaders in correcting mathematics wrong questions

\begin{tabular}{|c|c|c|c|c|c|}
\hline Variable & student leader & $\mathbf{N}$ & M & SD & $\mathbf{t}$ \\
\hline \multirow{2}{*}{$\begin{array}{l}\text { Cognition of Correcting Wrong Problems in Mathematics } \\
\text { Behavioral Tendency to Correct Mathematical Problems }\end{array}$} & Yes & 199 & 4.11 & 0.75 & \multirow[t]{2}{*}{$2.616^{\text {** }}$} \\
\hline & No & 376 & 3.93 & 0.87 & \\
\hline \multirow{2}{*}{ Emotion for correcting wrong math problems } & Yes & 199 & 3.83 & 0.64 & \multirow[t]{2}{*}{$5.015^{* * *}$} \\
\hline & No & 376 & 3.53 & 0.77 & \\
\hline \multirow{2}{*}{$\begin{array}{l}\text { Cognition of Correcting Wrong Problems in Mathematics } \\
\text { Behavioral Tendency to Correct Mathematical Problems }\end{array}$} & Yes & 199 & 3.95 & 0.70 & \multirow[t]{2}{*}{$3.540^{* * * *}$} \\
\hline & No & 376 & 3.72 & 0.75 & \\
\hline \multirow[b]{2}{*}{ Emotion for correcting wrong math problems } & Yes & 199 & 3.93 & 0.59 & \multirow[t]{2}{*}{$4.365^{* * * *}$} \\
\hline & No & 376 & 3.68 & 0.69 & \\
\hline
\end{tabular}

Note: $\mathrm{N}$ represents the number of students, $\mathrm{M}$ represents the mean, SD represents the standard deviation. The $\mathrm{t}$ test is to calculate the value of the $t$ statistic, which is used for the mean difference test. If the significant $p$-value is less than 0.01 , "(**)" will be added next to the $\mathrm{t}$ value; if the significant p-value is less than 0.001 , "(***)" will be added next to the $\mathrm{t}$ value.

It can be seen from Table 7 that there is a note beside the t-values of the corrected mathematics wrong attitude and cognition, behavior tendency, and emotion, and the significance $\mathrm{p}$-value is less than 0.01 , reaching a significant level. There are significant differences in student cadres, and the attitude of student cadres in correcting math wrong questions and the 
average value of each dimension are significantly

higher than non-student cadres.

Whether the teacher in charge of the mathematics teacher corrects the difference in the attitude of the Junior and Senior High school students to the wrong math problems

Table 8 Differences in attitudes of Junior and Senior High school students who correct mathematics wrong questions for mathematics teachers

\begin{tabular}{|c|c|c|c|c|c|}
\hline Variable & Leader class is a math teacher & $\mathrm{N}$ & $\mathrm{M}$ & SD & $\mathrm{t}$ \\
\hline \multirow{2}{*}{$\begin{array}{l}\text { Cognition of Correcting Wrong Problems in } \\
\text { Mathematics } \\
\text { Behavioral Tendency to Correct Mathematical } \\
\text { Problems }\end{array}$} & Yes & 306 & 4.12 & 0.75 & \multirow[t]{2}{*}{$4.122^{* * *}$} \\
\hline & No & 269 & 3.84 & 0.89 & \\
\hline \multirow{2}{*}{ Emotion for correcting wrong math problems } & Yes & 306 & 3.78 & 0.70 & \multirow[t]{2}{*}{$4.915^{* * *}$} \\
\hline & No & 269 & 3.48 & 0.76 & \\
\hline \multirow{2}{*}{$\begin{array}{l}\text { Cognition of Correcting Wrong Problems in } \\
\text { Mathematics } \\
\text { Behavioral Tendency to Correct Mathematical } \\
\text { Problems }\end{array}$} & Yes & 306 & 3.89 & 0.68 & \multirow[t]{2}{*}{$3.186^{* *}$} \\
\hline & No & 269 & 3.69 & 0.80 & \\
\hline \multirow{2}{*}{ Emotion for correcting wrong math problems } & Yes & 306 & 3.90 & 0.61 & \multirow[t]{2}{*}{$4.869^{* * *}$} \\
\hline & No & 269 & 3.63 & 0.71 & \\
\hline
\end{tabular}

Note: $\mathrm{N}=$ the number of students, $\mathrm{M}=$ the mean, $\mathrm{SD}=$ the standard deviation. The $\mathrm{t}$ test is to calculate the value of the $\mathrm{t}$ statistic, which is used for the mean difference test. If the significant p-value is less than 0.01 , "(**)" will be added next to the $\mathrm{t}$ value; if the significant $\mathrm{p}$-value is less than $0.001, "(* * *) "$ will be added next to the $\mathrm{t}$ value.

It can be seen from Table 7 that there is a note beside the t-values of correcting math wrong attitude and cognition, behavior tendency and emotion, and the significance p-value is less than 0.01 , reaching a significant level. There is a significant difference in whether the head teacher

is a math teacher, and the Junior and Senior High school students whose head teacher is a math teacher have higher attitudes in correcting math wrong questions and the average value of each dimension than the Junior and Senior High school students whose head teacher is not a math teacher.

Table 9 Correlation between attitudes to correcting mathematics wrong questions and various sub-dimensions and their mathematics academic performance

\begin{tabular}{|l|c|c|c|c|c|}
\hline & cognitive & $\begin{array}{l}\text { Behavioral } \\
\text { Tendency }\end{array}$ & Emotion & $\begin{array}{l}\text { Attitude towards } \\
\text { correcting } \\
\text { mathematics } \\
\text { wrong questions }\end{array}$ & $\begin{array}{c}\text { Mathematics } \\
\text { academic } \\
\text { performance }\end{array}$ \\
\hline $\begin{array}{l}\text { Cognition of Correcting Wrong } \\
\text { Problems in Mathematics }\end{array}$ & 1.000 & & & & \\
\hline $\begin{array}{l}\text { Behavioral Tendency to Correct } \\
\text { Mathematical Problems }\end{array}$ & $0.639^{* * * *}$ & 1.000 & & & \\
\hline $\begin{array}{l}\text { Emotion for correcting wrong math } \\
\text { problems }\end{array}$ & $0.521^{* * *}$ & $0.680^{* * * *}$ & 1.000 & & \\
\hline $\begin{array}{l}\text { Attitude towards correcting } \\
\text { mathematics wrong questions }\end{array}$ & $0.815^{* * * *}$ & $0.936^{* * *}$ & $0.820^{* * * *}$ & 1.000 & \\
\hline
\end{tabular}




\begin{tabular}{|l|l|l|l|l|l|}
\hline & & & & \\
\hline Mathematics academic performance & $0.403^{* * *}$ & $0.327^{* * *}$ & $0.277^{* * *}$ & $0.385^{* * *}$ & 1.000 \\
\hline
\end{tabular}

Note: The data in the table represents the correlation coefficient of product difference. If the significant $\mathrm{p}$ value is less than 0.001 , "(***)" will be added next to the correlation coefficient.

Five factors including cognitive subdimension, behavior tendency sub-dimension, affective sub-dimension, attitude to correct math wrong questions and mathematics academic performance are included in SPSS, and Pearson correlation analysis is performed to obtain correlation matrix (see Table 9). From the table, it is known that the division of the dimension of the attitude to correct math wrong questions is scientific and reasonable, because the correlation coefficients between the attitude of correcting math wrong questions and the three subdimensions are all greater than 0.5 , and reach a significant level of 0.001; Junior and Senior High school students' attitude to correct math wrong questions The correlation coefficient with the cumulative difference of mathematics academic performance is $0.385(\mathrm{p}<0.001)$, indicating that the two are significantly related; the correlation level between each dimension and mathematics academic performance has also reached a significant degree $(\mathrm{p}<0.001)$, so cognitive and behavioral tendencies, Emotion, or an effective way to improve math performance.

\section{The Influence of Junior and Senior High School} Students' Attitudes to Correcting Wrong Mathematics Questions on Mathematics

\section{Academic Achievement}

In order to explore the relationship between the attitude of correcting mathematics wrong questions and mathematics academic performance, on the basis of correlation, the attitude of correcting mathematics wrong questions as the independent variable and the mathematics academic performance as the dependent variable are established to establish a linear regression model to analyze the attitude of correcting mathematics error The specific impact on mathematics academic performance, this research use the least squares method to estimate the parameters, standardize the data during the calculation process, and get the specific regression equation as:

$$
(\mathrm{R} 2=0.148, \mathrm{t}=9.987, \mathrm{p}<0.001)
$$

From the model results, it can be seen that $\mathrm{R} 2$ is 0.148 , which means that the independent variable of "correcting mathematics wrong questions attitude" can explain $14.8 \%$ of the variance of "mathematics academic performance" variable. The standardized regression coefficient value is equal to 0.385 (a positive number), which means that the attitude of correcting mathematics wrong questions has a positive effect on the "mathematics academic performance" criterion variable. The t value of the significance test of the regression coefficient was 9.987 , and reached a significant level of 0.001 , so the attitude of correcting the wrong mathematics problem can significantly positively affect the mathematics academic performance. 
264 Investigation of Junior and Senior High School Students' Attitudes Towards Correcting Mistakes: A Case Study In Guilin - Xinxing Deng, Ying Zhou, Cunhua Liu

DOI: https://doi.org/10.31004/edukatif.v2i3.158

Analysis on the Overall Level of Junior and Senior High School Students' Attitudes to Correcting Mistakes

The results of the study show that the average value of Junior and Senior High school students' attitudes towards correcting mathematics wrong questions is 3.77 , which shows that Junior and Senior High school students have a more positive attitude towards maths wrong questions. Liu Ting once pointed out in "Survey and Research on High School Students' Attitudes towards Correcting Mathematics Wrong Questions" that "high school students' attitudes towards correcting mathematics wrong questions are generally more active."

This provides theoretical support for the results of this research to a certain extent. Among the three dimensions of correcting math wrong attitudes, the average value of the cognitive dimension $(M=3.99)>$ the average value of the affective dimension $(\mathrm{M}=3.80)>$ the average value of the behavioral orientation dimension ( $\mathrm{M}=3.64)$. Among them, the average value of "behavioral tendency to correct mathematics wrong questions" is the lowest. This dimension includes the methods of eliminating difficulties in correcting maths wrong questions, resisting interference in correcting maths wrong questions, and correcting math wrong questions.

Further analysis shows that when students encounter mathematical problems or are affected by the external environment, most students cannot persist in correcting their mistakes. In addition, some students did not master the correct method of correcting errors in the process of correcting mathematics wrong questions, but blindly corrected them, which seriously affected the quality of correcting students' wrong questions. Therefore, students should develop the habit of correcting mathematics wrong questions under the correct guidance of teachers to effectively manage them.

\section{Differential Analysis of Junior and Senior High}

School Students' Attitudes to Correcting Wrong Mathematical Problems

Independent sample T-test, Pearson correlation analysis, one-way analysis of variance and regression analysis are carried out through SPSS21.0 software. The data show that grade, gender, whether to serve as a student leader, whether the head teacher teaches mathematics, and mathematics academic performance all correct the attitude of Junior and Senior High school students to wrong math problems Has a significant impact:

(1) This study found that Junior and Senior High school students' attitudes towards correcting mathematics errors change with the development of grades. On the one hand, it may be due to the "utilitarianism" of senior students. They think that correcting mathematics wrong questions is timeconsuming and labor-intensive, and the use of "question sea tactics" yields faster results, so they pay less attention to them; On the one hand, the task of studying mathematics is getting heavier and students are more struggling to learn mathematics. Therefore, the more senior students are, the less willing they are to correct wrong math problems. This reminds teachers and parents to pay attention to the students' mathematics learning status in time, provide targeted guidance to students, and 
265 Investigation of Junior and Senior High School Students' Attitudes Towards Correcting Mistakes: A Case Study In Guilin - Xinxing Deng, Ying Zhou, Cunhua Liu

DOI: https://doi.org/10.31004/edukatif.v2i3.158

guide students to gradually develop a good habit of correcting a mistake.

(2) The attitude of girls in correcting a mistake is significantly higher than that of boys. This shows that compared with boys, girls agree with the value of wrong math problems and are more willing to invest time and energy on wrong math problems. When studied the current situation of the management of mathematics errors in the first year of high school students, girls are significantly better than boys in the value attitude towards correcting mistake. When Sun Guizhen analyzed the management of wrong questions in Junior and Senior High school students, she also found that girls can more accurately understand the importance of wrong management in mathematics, and their attitude towards wrong management is significantly higher than that of boys. Therefore, boys should increase the utilization rate of wrong mathematics questions, turn them into effective learning resources, and fully tap the value of the wrong math questions.

(3) The attitude of student cadres in correcting mathematics errors was significantly higher than that of non-student cadres. This is because student cadres are generally elected through elections and play a pioneering and exemplary role in all aspects. These students have high learning enthusiasm and their learning attitudes are generally correct, so they are more likely to adapt to mathematics learning. This enlightenment teachers should pay attention to teaching students in accordance with their aptitude, give more support to students in mathematics learning, and encourage students to persist in correcting mathematics errors in order to maximize the effectiveness of mathematics errors.

(4) Junior and Senior High school students whose head teacher is a math teacher have significantly higher attitudes towards correcting mathematics errors than those whose head teacher is not a math teacher. This may be because the head teacher is a Junior and Senior High school student who is a mathematics teacher, who can get more professional guidance in the process of mathematics learning, and it is easier to build confidence in learning mathematics. Therefore, the class teacher should overcome the differences in different subjects and personally demonstrate the effective method of correcting mathematics wrong questions, so that students can feel more support from teachers, thereby enhancing their confidence in learning mathematics.

\section{Analysis of the relationship between the attitude of correcting wrong mathematics questions and grades}

There is a significant correlation between mathematics academic performance and the attitude of correcting mathematics wrong questions, and the attitude of correcting mathematics wrong questions has a significant positive effect on mathematics achievement. the attitudes of the students who are good at learning to the wrong questions in mathematics are more correct, and their error management level is significantly better than that of the students with learning difficulties. the management level of wrong questions of the first-year senior students 
was significantly higher than that of the less advanced students. This

\section{ACKNOWLEDGEMENT}

I would like to thank Tommy Tanu Wijaya for helping me translate so that my thesis can be published in international journal. The author also thanks Professor Zhou for guiding the author so that the author can complete this research well.

\section{CONCLUSION}

Through further statistics and analysis, the status quo of Junior and Senior High school students' attitudes towards correcting mathematics wrong questions was found, and the following research conclusions were drawn: (1) Most Junior and Senior High school students have positive attitudes towards correcting math wrong questions; (3) The attitude of girls in correcting errors in mathematics is significantly higher than that of boys; (4) The attitude of student leaders in correcting errors in mathematics is significantly higher than that of non-student officials; (5) The head teacher is a Junior and Senior High school student whose math teacher is correcting mathematics. The attitude toward wrong questions is significantly higher than that of Junior and Senior High school students whose head teacher is not a mathematics teacher; (6) The attitude of correcting the wrong questions in mathematics and the correlation between each dimension and the academic performance of mathematics is significantly higher; Knowledge, behavioral orientation, and emotion are the starting points to improve mathematics academic performance.
Therefore, students should pay attention to the effective use of resources for mathematics wrong questions, and correct their attitudes towards correcting math wrong questions. On the one hand, students should pay attention to the "integration of knowledge and action" and include the correction of mathematics mistakes as part of their daily plan; on the other hand, students should improve the method of correcting mathematics mistakes and establish a set of mistakes. In the process, find The most suitable method for learning mathematics

\section{REFERENCES}

Aditya, P., Wijaya, T. T., Dewi, S. N., \& Zulfah, Z. (2020). Analisis Buku Siswa Matematika Sma Dari Indonesia Dan China Pada Materi Peluang Dan Statistik. Jurnal Cendekia: Jurnal Pendidikan Matematika, 4(2), 813822.

Aixia, W., Ying, Z., \& Wijaya, T. T. (2020). The current situation and prospect of study quality evaluation research in china in the last 10 years. EDUKATIF: JURNAL ILMU PENDIDIKAN, 2(1), 101-112.

Chai, C. S., Lim, C. P., \& Tan, C. M. (2016). Developing Teachers' Technological Pedagogical Mathematics Knowledge (TPMK) to Build Students' Capacity to Think and Communicate in Mathematics Classrooms. Future Learning in Primary Schools: A Singapore Perspective, 130-145. https://doi.org/10.1007/978-981-287-579-2

Fan, L., Zhu, Y., \& Miao, Z. (2013). Textbook research in mathematics education: Development status and directions. ZDM International Journal on Mathematics Education, $\quad$ 45(5), 633-646. https://doi.org/10.1007/s11858-013-0539-x

Huang, M. C. L., Chou, C. Y., Wu, Y. T., Shih, J. L., Yeh, C. Y. C., Lao, A. C. C., ... Chan, T. W. (2020). Interest-driven video creation for learning mathematics. In Journal of 
267 Investigation of Junior and Senior High School Students' Attitudes Towards Correcting Mistakes: A Case Study In Guilin - Xinxing Deng, Ying Zhou, Cunhua Liu

DOI: https://doi.org/10.31004/edukatif.v2i3.158

Computers in Education (Vol. 7). https://doi.org/10.1007/s40692-020-00161-w

Jatmiko, D. D. H., Fatahillah, A., Oktavianingtyas, E., \& Rochmah, O. A. (2020). An analysis of olympiad students' critical thinking in solving National Science Olympiad (OSN) problem on number theory material. Journal of Physics: Conference Series, 1563(1). https://doi.org/10.1088/1742-

6596/1563/1/012037

Laelasari, Darhim, \& Prabawanto, S. (2019). Analysis of students' mathematics resilience abilities on linear program material. Journal of Physics: Conference Series, 1280(4), 8$12 . \quad$ https://doi.org/10.1088/17426596/1280/4/042005

Mumcu, H. Y., \& Aktaş, M. C. (2020). Development of an attitude-towards-usingmathematics scale for high-school students and an analysis of student attitudes. International Journal of .... Retrieved from https://www.tandfonline.com/doi/abs/10.108 0/0020739X.2019.1679398

Nurfauziah, P., Faudziah, L., Nuryatin, S., \& Mustaqimah, I. A. (2018). Analisis Self Efficacy Matematik Siswa Kelas VIII SMP 7 Cimahi Dilihat dari Gender (Mathematical Self Efficacy Analysis of Grade VIII Students of SMP 7 Cimahi Viewed from Gender). Jurnal Matematika Dan Pendidikan Matematika, 3(1), 61-70.

Parsons, D., Inkila, M., \& Lynch, J. (2019). Navigating learning worlds: Using digital tools to learn in physical and virtual spaces. Australasian Journal of Educational Technology, 35(4), 144-159. https://doi.org/10.14742/ajet.3675

Pertiwi, I., \& Wahyudin. (2020). Analysis of elementary student's mathematical connection and communication ability. Journal of Physics: Conference Series, 1521(3). $\quad$ https://doi.org/10.1088/1742$6596 / 1521 / 3 / 032001$

Qin, L., Zhou, Y., \& Tanu, W. T. (2019). The Analysis of Mathematics Adversity Quotient of Left Behind Junior High School Students in Rural Areas. Open Journal of Social
Sciences,

$331-342$

https://doi.org/10.4236/jss.2019.710028

Retnawati, H., \& Wulandari, N. F. (2019). The development of students' mathematical literacy proficiency. Problems of Education in the 21st Century, 77(4), 502-514. https://doi.org/10.33225/pec/19.77.502

Sari, R. H. Y., \& Wutsqa, D. U. (2019). Analysis of student's error in resolving the Pythagoras problems. Journal of Physics: Conference Series, $1320(1)$.

https://doi.org/10.1088/17426596/1320/1/012056

Shieh, R. S., \& Chang, W. (2014). Fostering student's creative and problem-solving skills through a hands-on activity. Journal of Baltic Science Education, 13(5), 650-661.

Shinariko, L. J., Saputri, N. W., Hartono, Y., \& Araiku, J. (2020). Analysis of students' mistakes in solving mathematics olympiad problems. Journal of Physics: Conference Series, 1480(1). https://doi.org/10.1088/17426596/1480/1/012039

Surya, Y. F., Zulfah, Astuti, Marta, R., \& Wijaya, T. T. (2020). The Development of OpenEnded Math Questions on Grade v Students of Elementary School. Journal of Physics: Conference $\quad$ Series, $1613(1)$. https://doi.org/10.1088/1742$6596 / 1613 / 1 / 012081$

Susanti, E., \& Hartono. (2019). An analysis mathematical problem solving and mathematical critical thinking skills of junior high school students. Journal of Physics: Conference $\quad$ Series, $1320(1)$. https://doi.org/10.1088/1742$6596 / 1320 / 1 / 012071$

Takeuchi, H., \& Shinno, Y. (2020). Comparing the Lower Secondary Textbooks of Japan and England: a Praxeological Analysis of Symmetry and Transformations in Geometry. International Journal of Science and Mathematics Education, 18(4), 791-810. https://doi.org/10.1007/s10763-019-09982-3

Villalba-condori, K. O., Lavonen, A. A. J., \& Eds, 
268 Investigation of Junior and Senior High School Students' Attitudes Towards Correcting Mistakes: A Case Study In Guilin - Xinxing Deng, Ying Zhou, Cunhua Liu

DOI: https://doi.org/10.31004/edukatif.v2i3.158

L. W. T. W. (2019). Education and Technology in Sciences. https://doi.org/10.1007/978-3-030-45344-2

Wijaya, T.T., Tang, J., \& Purnama, A. (2020). Developing an interactive mathematical learning media based on the tpack framework using the hawgent dynamic mathematics software. In Lecture Notes of the Institute for Computer Sciences, Social-Informatics and Telecommunications Engineering, LNICST. https://doi.org/10.1007/978-3-030-600365_24

Wijaya, T.T., Ying, Z., Chotimah, S., Bernard, M., Zulfah, Z., \& Astuti, A. (2020). Hawgent dynamic mathematic software as mathematics learning media for teaching quadratic functions. Journal of Physics: Conference Series, 1592(1). https://doi.org/10.1088/1742$6596 / 1592 / 1 / 012079$

Wijaya, T.T., Ying, Z., \& Purnama, A. (2020). Using Hawgent dynamic mathematics software in teaching trigonometry. International Journal of Emerging Technologies in Learning, 15(10). https://doi.org/10.3991/ijet.v15i10.13099

Wijaya, Tommy Tanu. (2021). How chinese students learn mathematics during the coronavirus pandemic. International Journal of Educational Research and Innovation (IJERI), 15, 1-16. https://doi.org/https://doi.org/10.46661/ijeri.4 950

$\mathrm{Xu}, \mathrm{C} ., \mathrm{Wu}, \mathrm{L} .$, \& Wang, S. (2020). for Image Classification Using Regularized Convolutional Auto-Encoder (Vol. 3). https://doi.org/10.1007/978-3-030-17795-9

Yang, D. C., \& Sianturi, I. A. (2017). An Analysis of Singaporean versus Indonesian textbooks based on trigonometry content. Eurasia Journal of Mathematics, Science and Technology Education, 13(7), 3829-3848. https://doi.org/10.12973/eurasia.2017.00760a

Yang, D. C., Tseng, Y. K., \& Wang, T. L. (2017). A comparison of geometry problems in middle-grade mathematics textbooks from Taiwan, Singapore, Finland, and the United
States. Eurasia Journal of Mathematics, Science and Technology Education, 13(7), 2841-2857.

https://doi.org/10.12973/eurasia.2017.00721a

Yi, L., Ying, Z., \& Wijaya, T. T. (2019). The Trend of Mathematics Teaching Method Has Change From Fragments To Systematics. Journal Cendekia: Jurnal Pendidikan Matematika, 3(2), 471-480. https://doi.org/10.31004/cendekia.v3i2.137

Zhang, L., Zhou, Y., \& Wijaya, T. T. (2020). Hawgent dynamic mathematics software to improve problem-solving ability in teaching triangles. Journal of Physics: Conference Series, 1663(1). https://doi.org/10.1088/17426596/1663/1/012069

Zulfah, Astuti, Surya, Y. F., Marta, R., \& Wijaya, T. T. (2020). Measurement of mathematics problems solving ability using problem based mathematics question. Journal of Physics: Conference Series, 1613(1). https://doi.org/10.1088/17426596/1613/1/012026 